\title{
DEIGN OF SIMPLE RECYCLING AC ELECTRICAL ENERGY GENERATION SYSTEM WITH SMALL DC INPUT \& HIGH EFFICIENCY WITH GOOD LOAD HANDLING CAPABILITY
}

\author{
Shaik Rasheed Ahameed \\ Newton Institute Of Engineering, Alluguraja Palli, Koppunur Post, Macherla, Guntur District, AP, India 522426.
}

\begin{abstract}
The main intention of this research work is to design low cost AC electrical energy generation implementation system without any mechanical energy input (Diesel, wind, hydel, coal, solar and nuclear energy system). This concept main ambition to save global warming to save the people from radiation. This system transmits the power with low cost to the consumers and industrial companies. This work don't depends on any renewable energy sources.This Deign Of Simple Recycling AC Electrical Energy Generation System with Small DC Input \& High Efficiency with Good Load Handling Capability, main motive is to supply power with[1] low cost for formers, household and industrials. The main purpose of research work is to implement zero co $\mathrm{c}_{2}$ emission automotive. How I justify this thing means the vehicle runs with electrical energy input.

For this experiment I took up one battery source with suitable configuration which drives the dc motor. The dc motor coupled to ac alternator with specialized speed governing mechanism is employed in between alternator and DC machine with rated speed. We collect energy from the stator of the machine. The collected energy is able to drive the electrical appliances ( Motors, Fans,etc.,). This energy is feedback to input dc battery with specialized arrangement. Here stickily mentioned that this process completely recycled once the battery is recharged at first. I strictly pronounced that my research can change the present day's scenarios to achieve global worming free world.
\end{abstract}

\section{INTRODUCTION}

\subsection{Electricity Generation}

Electricity generation is the process of generating electrical power from other sources of primary energy. The fundamental principles of electricity generation were discovered during the 1820 s and early 1830 s by the British scientist Michael Faraday. His basic method is still used today:[2] electricity is generated by the movement of a loop of wire, or disc of copper between the poles of a magnet For electric utilities, it is the first process in the delivery of electricity to consumers. The other processes, electricity transmission, distribution, and electrical power storage and recovery using pumped-storage methods are normally carried out by the electric power industry. Electricity is most often generated at a power station by electromechanical generators, primarily driven by heat engines fueled by chemical combustion or nuclear fission but also by other means such as the kinetic energy of flowing water and wind. Other energy sources include solar photovoltaic and geothermal power.

\subsection{Dynamo}

A dynamo is an electrical generator that produces direct current with the use of a commutator. Dynamos were the first electrical generators capable of delivering power for industry, and the foundation upon which many other later electricpower conversion devices were based, including the electric motor, the alternating-current alternator, and the rotary converter. Today, the simpler alternator dominates large scale power generation, for efficiency, reliability and cost reasons. A dynamo has the disadvantages of a mechanical commutator. Also, converting alternating to direct current using power rectification devices (vacuum tube or more recently solid state) is effective and usually economic. The word dynamo (from the Greek word dynamis; meaning power) was originally another name for an electrical generator, and still has some regional usage as a replacement for the word generator. 


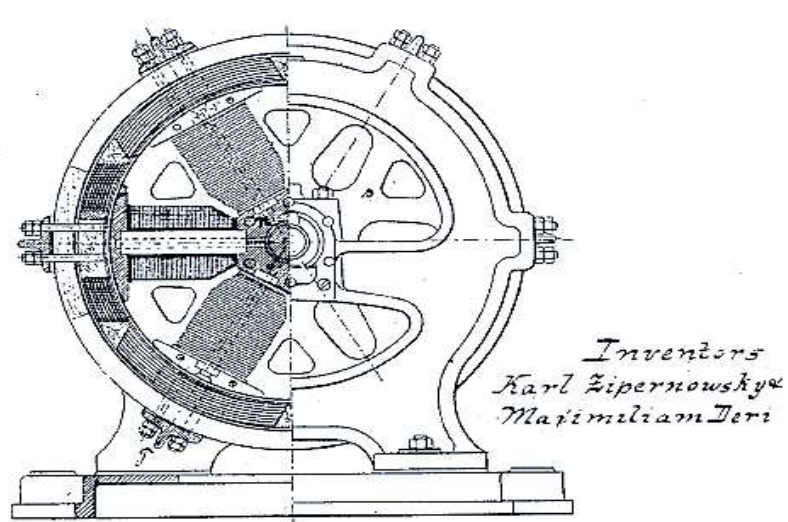

Fig 1: Cross section view of Dynamo

\subsection{Electric Battery}

An electric battery is a device consisting of one or more electrochemical cells that convert stored chemical energy into electrical energy. Each cell contains a positive terminal, or cathode, and a negative terminal, or anode[3]. Electrolytes allow ions to move between the electrodes and terminals, which allows current to flow out of the battery to perform work.

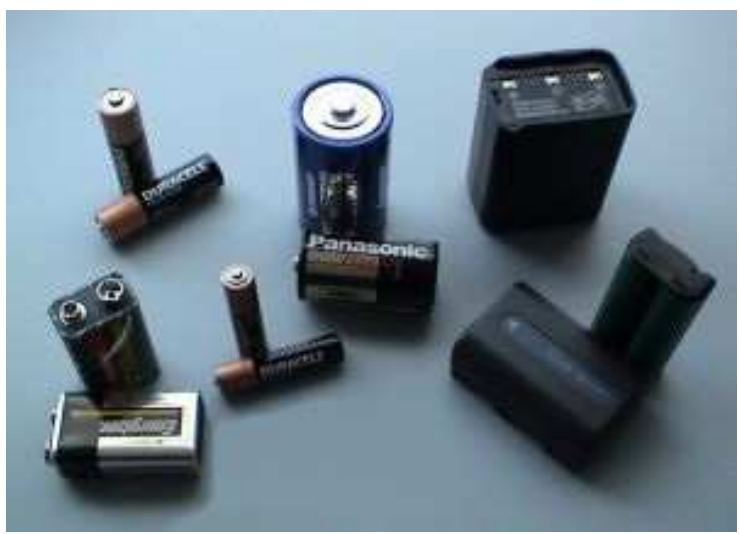

Fig2: Different kind of storage batteries

\subsection{Motor:}

A DC motor is a mechanically commutated electric motor powered from direct current (DC). The stator is stationary in space by definition and therefore the current in the rotor is switched by the commutator to also be stationary in space. This is how the relative angle between the stator and rotor magnetic flux is maintained near 90 degrees, which generates the maximum torque.

DC motors have a rotating armature winding (winding in which a voltage is induced) but non-rotating armature magnetic field and a static field winding (winding that produce the main magnetic flux) or permanent magnet. Different connections of the field and armature winding provide different inherent speed/torque regulation characteristics. The speed of a DC motor can be controlled by changing the voltage applied to the armature or by changing the field current. The introduction of variable resistance in the armature circuit or field circuit allowed speed control. Modern DC motors are often controlled by power electronics systems called DC drives.

\subsection{AC Adapter}

The AC adapter, AC/DC adapter or AC/DC converter is a type of external power supply, often enclosed in a case similar to an AC plug. Other names include plug pack, plug-in adapter, adapter block, domestic mains adapter, line power adapter, wall wart, or power adapter; adapters for battery-powered equipment may be described as chargers. AC adapters are used with electrical devices that require power but do not contain internal components to derive the required voltage and power from mains power. The internal circuitry of an external power supply is very similar to the design that would be used for a built-in or internal supply.

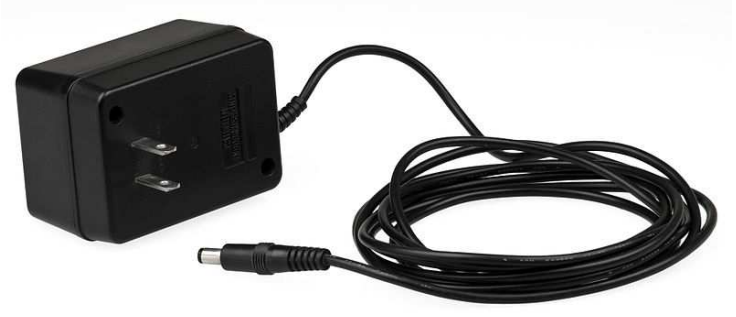

Fig: 3 AC Adapter

\section{RELATED WORK AND RESULT DISCUSSION}

D.C electrical to A.C Electrical Energy System Generator is running completely battery current running generator this system one side battery current on the generator[5], one side generator power is using and other side battery charging process.

This system battery charging Process is two types

$>$ Slow charging process

$>$ Fast charging process

Slow Charging Process: This process battery charging is slow process. Slow charging process power generation time battery charging is very slow.

Fast Charging Process: This process battery charging is fast process. Fast charging process power generation time battery charging is very fast. This process successful complete recycling process. 
Economical problem introducing my experiment slow charging process. Slow charging process

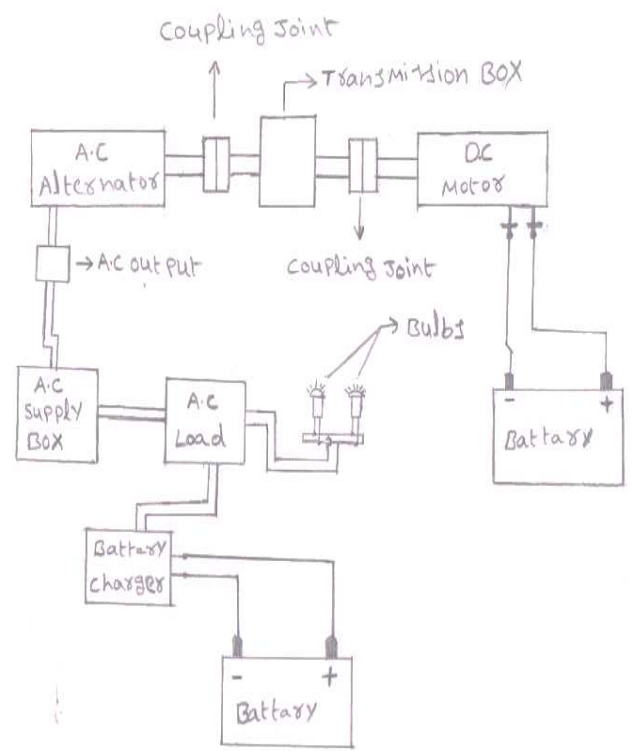

Fig 4: Block diagram of generator

\subsection{OFF Position of Generator:}

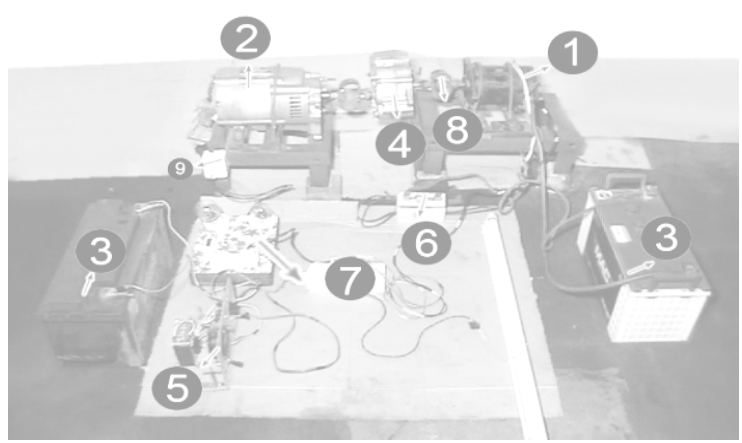

Fig 5:- OFF position generator

1. D.C motor $12 \mathrm{v}$

2. A.C alternator,

3. Batteries

4. Transmission box

5. Battery charger,

6. Fuse,

7. Power supply boxes,

8. Joint coupling

9. Output A.C supply

\subsection{ON Position Generator:}

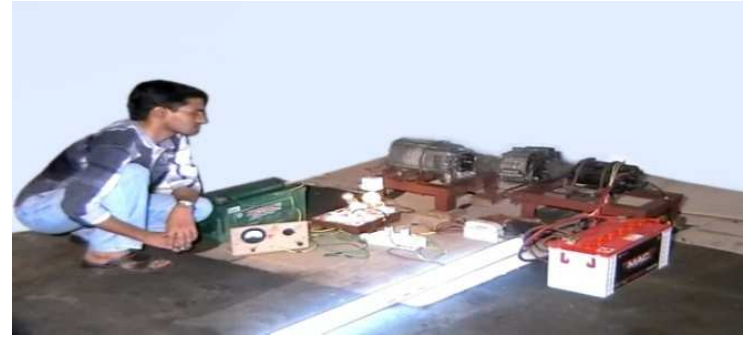

Fig 6:- ON Position Generator

\subsection{OFF Position Battery Charger:}

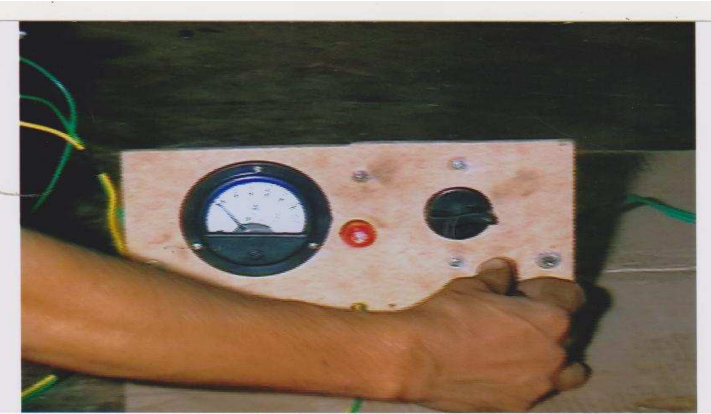

Fig 7:- OFF Position Battery Charger

\subsection{ON Position Battery Charger:}

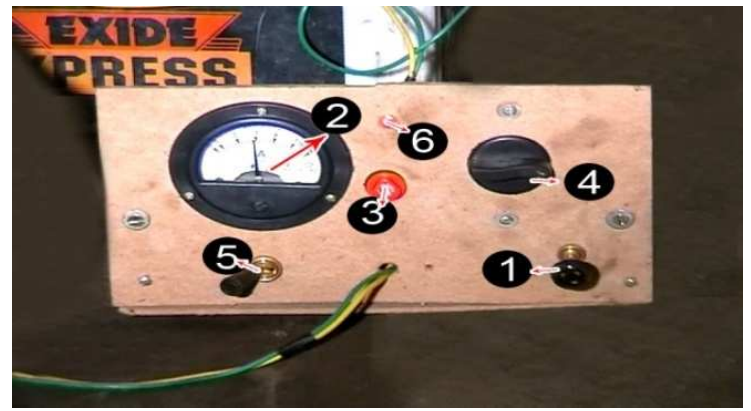

Fig 8:- ON position battery charger

1. on/off switch

2. Ammeter,

3. Fuse,

4. Voltage controlling switch

5. Voltage convert switch,

6. Indicator.

\subsection{A.C Alternator}

Single phase A.C Alternator introduce the plane recycling battery charging process. This system one side battery power running generator, one side generator power use and battery recycling charging process A.C Alternator is used. 


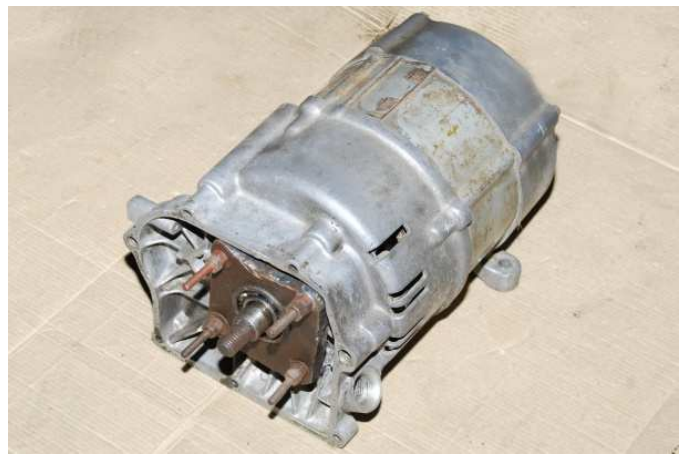

Fig 9: A.C Alternator

\subsection{2v D.C Motor}

This D.C motor provides the torque generate the A.C current. D.C motor provide only electrical energy this motor provide the torque given $12 \mathrm{v}$ battery current.

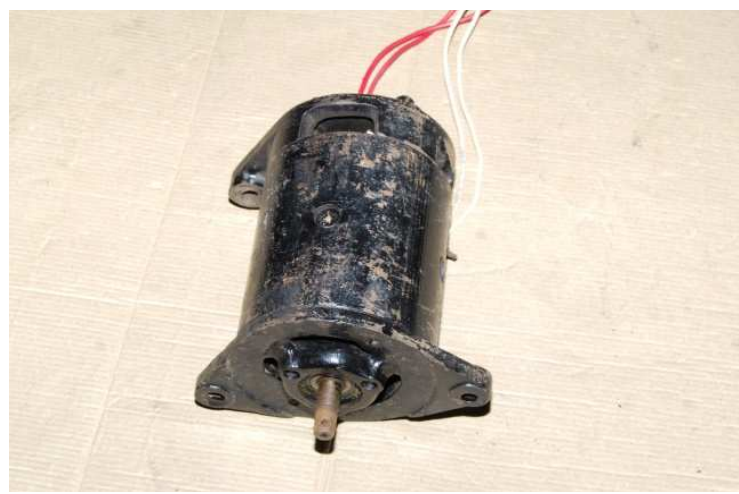

Fig 10: 12v D.C Motor

\subsection{Battery Charger}

Design of D.C electrical to A.C Electrical energy system $12 \mathrm{v}$ battery charging process is used to $12 \mathrm{v}$ battery charger recycling process most important.

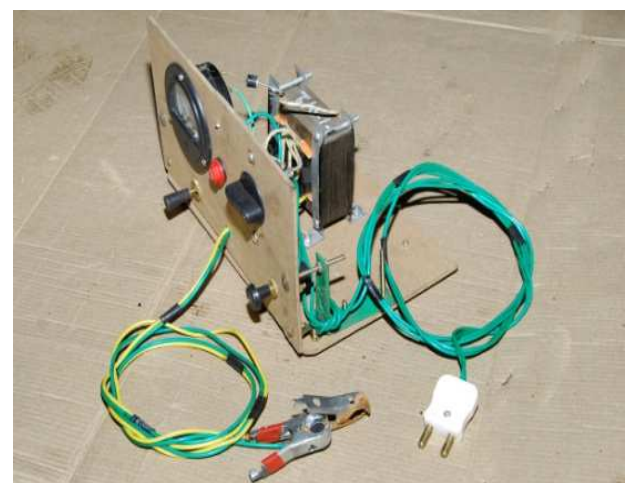

Fig 11: Battery Charger

\subsection{2v Battery}

This power generator system generator uses the $12 \mathrm{v}$ battery, current.

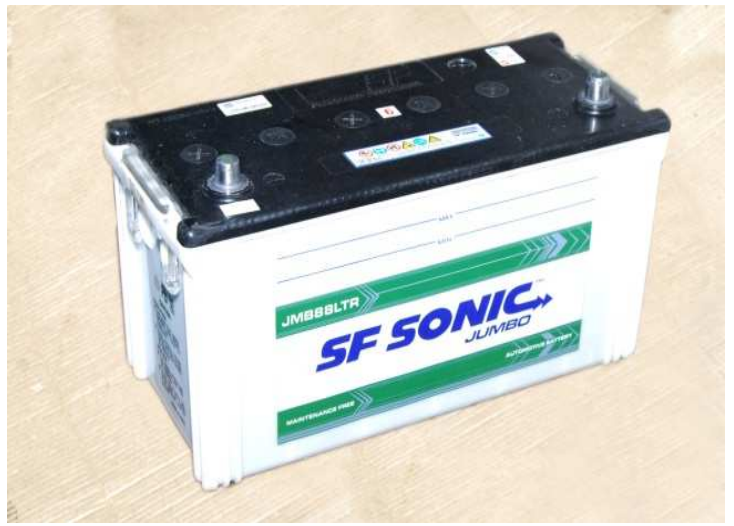

Fig 12: 12v Battery

\subsection{Transmission Box}

Transmission box is used the generator required torque provide the A.C Alternator maximum 3000 to $3500 \mathrm{rpm}$ generate the 230v A.C current.

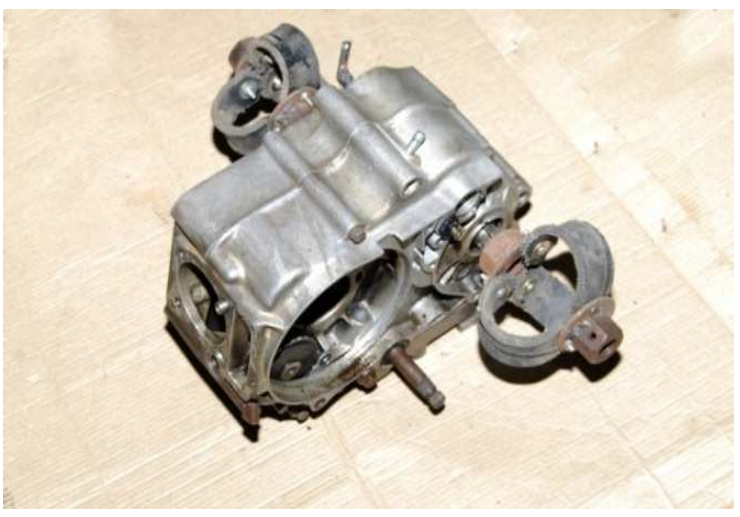

Fig 13: Transmission box

\section{CONCLUSIONS}

This research work provides simple operating mechanism and process in not complex one and also This works makes the battery to be charge rapidly( battery charged upto 99\%), this process is called fast recycling process. Where as in the case of slow charging process the battery charge up to $50 \%$. In this work we achieved charging of battery up to $99 \%$ and also showed the best efficient recycling power generation mechanism with small amount DC power input. And mention thing is the input is DC source. This work very useful for future to decrees global warming and to build zero co2 emission vehicles. 


\section{ACKNOWLEDGEMENTS}

The current ADE Mr. Bhaskar Rao who is working in 400KV POWER GRID,Talla Paliy,Macherla, Guntur, district, Andhra Pradesh, India 522426 supported this work. Here said this project can hold future to solve so many power problems.

The news paper statement of him as follow in the date 23/09/2013 in eenadu telugu paper, in Guntur district edition.

And also I would like to acknowledge the following people of Newton's institute of Engineering (Director Mr. K.Nagarjuna Redddy, The secretary Mr J. Srinivasa Reddy, and hod of EEE Mr. Suresh), Aluguraja palli,,koppunure post, macherla, Guntur dist, A.P., for support.

\section{REFERENCES}

[1] 'The Institution of Engineering \& Technology: Michael Faraday'

[2] Jump up_^ In 1881, under the leadership of Jacob Schoellkopf, the first hydroelectric generating station was built on Niagara Falls.

[3] Jump up Pearl Street Station: The Dawn of Commercial Electric Power

[4] http://www.eia.doe.gov/cneaf/electricity/epm/table1_1. html

[5] (French) DGEMP / Observatoire de l'énergie (April 2007). "L'Electricité en France en 2006 : une analyse statistique." (PDF). Retrieved 2007-05-23.

[6] Jump up _ "piezoelectric generator". Retrieved 2012-0520.

[7] Jump up Reuters News Service (2005-12-30). "Mohave Power Plant in Nevada to Close as Expected". Planet Ark. Retrieved 2007-07-16.

[8] Jump up_ New World Record Achieved in Solar Cell Technology (press release, 2006-12-05), U.S. Department of Energy.

[9] Jump up World's Largest Utility Battery System Installed in Alaska (press release, 2003-09-24), U.S. Department of Energy. "13,670 nickel-cadmium battery cells to generate up to 40 megawatts of power for about 7 minutes, or 27 megawatts of power for 15 minutes."

\section{BIOGRAPHIE:}

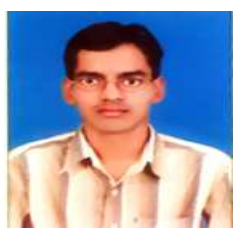

Shaik Rasheed Ahameed s/o S.K Ameer( RTC Mechanic) . Door.No:11-1-375,busi bazar, machelra, Guntur district A.P, India 522426. He completed, B,tech in the stream of Electrical and Electronics Engineering at Newton's institute of engineering, macherla. His research interest are power systems and co computer aided power engineering and optimal power system generation and controlling.

Email Id: Rasheedahmed123@gmail.com 